\title{
Relationship between sexual offences and mental and developmental disorders: a review
}

\author{
Relação entre crimes sexuais e transtornos mentais e do desenvolvimento: uma revisão
}

\author{
Alexandre Martins Valença ${ }^{1,2}$, Isabella Nascimento 2 , Antonio Egidio Nardi ${ }^{2}$ \\ ${ }^{1}$ Centre of Medical Science, Department of Mental Health and Psychiatry, Federal University Fluminense of Niterói (UFF), Rio de Janeiro, RJ, Brazil. \\ 2 Institute of Psychiatry, Federal University of Rio de Janeiro (IPUB-UFRJ), Rio de Janeiro, RJ, Brazil.
}

Received: 9/20/2012 - Accepted: 12/20/2012

\begin{abstract}
Background: Sexual violence is a serious public health problem that concerns and faces our society. The prevalence, magnitude and consequences of this problem have merited growing attention by health researchers and human rights scholars. Objective: To conduct a review of the literature regarding the relationship between mental disorders, sexual offences and those of development. Methods: A bibliographic research was performed in PubMed, Scientific Electronic Library Online (SciELO) and Lilacs, employing the terms "sexual crime", "sexual offence", "mental disorder", "mental retardation", "developmental disability" and its combinations. Results: The mental disorders and developmental disorders more frequently related to the perpetration of sexual offences were schizophrenia, bipolar disorder and mental retardation. Discussion: The detection and treatment of psychiatric morbidity among sexual offenders in health and criminal justice systems, which may contribute to a lower risk of recidivism of this sexual behaviour, is important.
\end{abstract}

Valença AM, et al. / Rev Psiq Clín. 2013;40(3):97-104

Keywords: Sexual crime, sexual offence, mental disorder, mental retardation, developmental disability.

\section{Resumo}

Contexto: A violência sexual é um grave problema de saúde pública que preocupa e confronta nossa sociedade. A prevalência, a magnitude e as consequências desse problema têm merecido atenção crescente por parte de estudiosos e pesquisadores da saúde e dos direitos humanos. Objetivo: Realizar uma revisão bibliográfica sobre a relação entre crimes sexuais e transtornos mentais e do desenvolvimento. Métodos: Foi realizada uma pesquisa bibliográfica nas bases de dados do PubMed, Scientific Eletronic Library Online (SciELO) e Lilacs, utilizando os descritores "sexual crime", "sexual offense", "mental disorder", "mental retardation", "developmental disability" e suas combinações. Resultados: Os transtornos mentais e do desenvolvimento mais frequentemente relacionados à perpetração de crimes sexuais foram esquizofrenia, transtorno bipolar e retardo mental. Conclusão: São importantes a detecção e o tratamento da morbidade psiquiátrica entre ofensores sexuais nos sistemas de saúde e de justiça criminal, o que pode contribuir para menor risco de reincidência desse comportamento sexual.

Valença AM, et al. / Rev Psiq Clín. 2013;40(3):97-104

Palavras-chave: Crime sexual, ofensa sexual, transtorno mental, retardo mental, transtorno do desenvolvimento.

\section{Introduction}

Sexual offence is a serious problem which our society has to face continually, including a behaviour in which there may or may not be physical contact, involving victims of both sexes and of all ages and being considered a violent type of behaviour. Sexual violence is characterised when there is an effective sexual contact, a threat or an attempt, with no consent by the other person, or the other person is not able to give their consent ${ }^{1}$. In fact, sexual offences are all those defined as such by the current law in a certain country or culture. In reality, it is not a medical or psychological construct; it is solely a social legal construct, with variable conceptual possibilities over the length of history and the geographical location.

Sexual violence is a serious problem of public health to be faced by our society. In the State of São Paulo, approximately $4 \%$ of imprisoned men are serving sentence due to sexual offences ${ }^{2}$. It is estimated that the police records correspond to around $10 \%$ or $20 \%$ of the real number of cases that occur. The situation of sub-notification being attributed as a possible cause for the absence of data ${ }^{3}$. The decision of the victim in not registering the offence, the absence of physical traumas in the expert examinations, the fact that the aggressor is a close relative of the victim or the victim being a minor or having a mental disorder or serious mental illness, the fear of the reaction of the aggressor and of suffering embarrassment and humiliation, apart from incomplete expert registers, may also contribute to the lack of data.

There are estimates that between $10 \%$ and $16 \%$ of men and between $20 \%$ and $27 \%$ of women have been victims of sexual abuse in their childhood ${ }^{4}$. The British Crime Survey, for example, made an estimate that one in every ten women had already been sexually victimized by the age of 16, and that less than one in every five incidents of sexual victimization in women resulted in police investigation (Siegel, 2000, apud Baltieri and Andrade ${ }^{5}$ ). Rape and attempted rape are the two most common violent sexual offences.

This violence is also evident in state institutional settings that contain children or vulnerable adults, such as prisons, juvenile detention centres and forensic mental health hospitals. Some of the review studies have shown that many sexual aggressors can show psychiatric problems, such as, psychosis, mood disorder and mental retardation ${ }^{6}$. We will call attention to these aspects during the length of the presentation of the scientific literature review studies both on a national and international level.

The general objective of this study is to undertake a bibliographical review regarding the relationship between sexual offences, mental disorders and mental retardation. The specific objectives have been 
to observe which were the main mental and developmental disorders presented by perpetrators of sexual offences; which sexual offences are more frequently committed and what are the associated factors and the motives related to the practice of these offences. It has not been the objective of this study to evaluate the relationship between sexual offences and disorders related to the use of alcohol and/or drugs, however, these disorders will be mentioned when they have been inserted in the context of studies on sexual offences associated to mental and developmental disorders, including when there are issues of comorbidity in the latter.

\section{Methodology}

A review of the literature was undertaken, through the PubMed database, Scientific Eletronic Library Online (SciELO) and Lilacs, between the years 2000 and 2012. The following key words were applied: sexual crime, sexual offence, mental disorder, mental retardation, developmental disability and its combinations. In the Medline system the section of related articles was also researched. With the purpose of expanding our research, we also consulted the references of the articles found and texts of related books on this subject matter. Studies with samples of individuals and review studies were also considered. Case study reports were excluded.

\section{Results}

Thirty nine articles published between 1987 and 2011 were found, which fulfilled the criteria for this study. Of these, 23 were studies with samples of individuals who were perpetrators of sexual offences (Table 1).

Table 1. Summary of the studies with samples of individuals who perpetrated sexual crimes

\begin{tabular}{|c|c|c|c|c|c|c|}
\hline Authors & Year & Methodology & $\begin{array}{l}\text { Sample } \\
\text { (n) }\end{array}$ & Main Psychiatric Diagnosis & Sexual Offences & Factors and Associated Motives \\
\hline Fazel et al.10 & 2007 & Case control & 8.495 & $\begin{array}{l}\text { Schizophrenia ( } n=130) \text {, other } \\
\text { psychosis's ( } n=212) \text {, bipolar } \\
\text { disorder ( } n=27) \text {, organic mental } \\
\text { disorder ( } n=44) \text {, abuse and/or } \\
\text { dependence on alcohol and or } \\
\text { substances ( } n=6) \text {, personality } \\
\text { disorder ( } n=215)\end{array}$ & $\begin{array}{l}\text { Rape and sexual abuse in } \\
\text { children }\end{array}$ & $\begin{array}{l}\text { Existence of mental disorder, } \\
\text { problems of relationship, deviant } \\
\text { sexual preferences }\end{array}$ \\
\hline $\begin{array}{l}\text { Craissati and } \\
\text { Hodes }^{11}\end{array}$ & 1992 & Serial cases study & 11 & $\begin{array}{l}\text { Schizophrenia }(n=10) \text {, "affective } \\
\text { psychosis" }(n=1)\end{array}$ & $\begin{array}{l}\text { Rape or attempt rape, indecent } \\
\text { exposure }\end{array}$ & Illness recidivism \\
\hline Phillips et al. ${ }^{12}$ & 1999 & Serial cases study & 15 & Schizophrenia & Rape and indecent exposure & Psychotic symptomatology \\
\hline Smith13 & 2000 & $\begin{array}{l}\text { Retrospective study of } \\
\text { records }\end{array}$ & 80 & Schizophrenia & $\begin{array}{l}\text { Rape or attempted rape, or } \\
\text { indecent exposure }\end{array}$ & $\begin{array}{l}\text { Psychotic symptomatology, } \\
\text { cognitive distortions, deviant } \\
\text { fantasies }\end{array}$ \\
\hline Alden et al. ${ }^{14}$ & 2007 & Birth cohort study & 173.559 & $\begin{array}{l}\text { Schizophrenia ( } n=1,143), \\
\text { organic mental disorder } \\
(n=1,030), \text { "affective psychosis" } \\
(n=942), \text { other psychosis's ( } n \\
=1,309)\end{array}$ & $\begin{array}{l}\text { Rape, paedophilia, indecent } \\
\text { exposure, voyeurism, } \\
\text { exhibitionism }\end{array}$ & $\begin{array}{l}\text { Presence of psychotic disorder } \\
\text { associated to personality } \\
\text { disorders or disorders related } \\
\text { to drugs }\end{array}$ \\
\hline Alish et al..$^{15}$ & 2007 & $\begin{array}{l}\text { Retrospective study of } \\
\text { hospitalized individuals }\end{array}$ & 173 & $\begin{array}{l}\text { Schizophrenia and sexual } \\
\text { offence ( } n=36) \text {, schizophrenia } \\
\text { with no sexual offence }(n=80) \text {, } \\
\text { paraphilia ( } n=29) \text {, disorder } \\
\text { related to the use of alcohol and } \\
\text { substances ( } n=28 \text { ) }\end{array}$ & $\begin{array}{l}\text { Rape and sexual violations } \\
\text { without penetration }\end{array}$ & $\begin{array}{l}\text { Presence of comorbid paraphilia } \\
\text { to schizophrenia and personality } \\
\text { disorder }\end{array}$ \\
\hline Fazel et al. ${ }^{17}$ & 2010 & Birth cohort study & 37.429 & Bipolar disorder $(n=3,743)$ & Not specified & $\begin{array}{l}\text { Comorbidity of bipolar disorder } \\
\text { with abuse of drugs }\end{array}$ \\
\hline Curtin e Niveau ${ }^{18}$ & 1998 & $\begin{array}{l}\text { Retrospective study of } \\
\text { expert documents }\end{array}$ & 67 & $\begin{array}{l}\text { Schizophrenia and other } \\
\text { psychosis's }(5 \%) \text {, dependence on } \\
\text { alcohol }(13 \%) \text {, dependence on } \\
\text { drugs }(5 \%) \text {, affective disorders } \\
(13 \%) \text {, paraphilias }(15 \%), \\
\text { personality disorders }(47 \%)\end{array}$ & $\begin{array}{l}\text { Rape or attempted rape, other } \\
\text { acts of sexual coercion }\end{array}$ & $\begin{array}{l}\text { Record of sexual abuse in } \\
\text { childhood, leading to sexual } \\
\text { abuse of children in adult life }\end{array}$ \\
\hline Dunsieth et al.20 & 2004 & $\begin{array}{l}\text { Transversal evaluation of } \\
\text { individuals }\end{array}$ & 113 & $\begin{array}{l}\text { Disorders related to the use of } \\
\text { drugs }(n=84) \text {, paraphilias ( } n= \\
84) \text {, mood disorders }(n=66), \\
\text { impulse control disorder }(n=43), \\
\text { anxiety disorder }(n=26)\end{array}$ & $\begin{array}{l}\text { Rape or attempted rape, sexual } \\
\text { coercion, sexual abuse in } \\
\text { children }\end{array}$ & $\begin{array}{l}\text { Paraphilias associated to mood } \\
\text { and anxiety disorder }\end{array}$ \\
\hline Leue et al.21 & 2004 & $\begin{array}{l}\text { Transversal evaluation of } \\
\text { individuals }\end{array}$ & 55 & $\begin{array}{l}\text { Paraphilias }(n=30) \text {, impulse } \\
\text { control disorder }(n=25) \text {, simple } \\
\text { phobia }(n=22) \text {, social phobia ( } \\
=21), \text { PTSD }(n=15) \text {, depression } \\
(n=29)\end{array}$ & $\begin{array}{l}\text { Rape and sexual abuse in } \\
\text { children }\end{array}$ & $\begin{array}{l}\text { Paraphilias and impulse control } \\
\text { disorders and comorbidity with } \\
\text { mental disorders }\end{array}$ \\
\hline Crocker et al. ${ }^{24}$ & 2007 & $\begin{array}{l}\text { Transversal evaluation of } \\
\text { individuals, interview with } \\
\text { carers and study of medical } \\
\text { records }\end{array}$ & 296 & Mental retardation & $\begin{array}{l}\text { Not specified. Sexual offences } \\
\text { represent } 7.4 \%\end{array}$ & $\begin{array}{l}\text { Association with mental } \\
\text { disorders, greater impulsiveness } \\
\text { and antisocial tendencies }\end{array}$ \\
\hline Murrey et al.26 & 1992 & $\begin{array}{l}\text { Retrospective study of } \\
\text { medical records }\end{array}$ & 106 & $\begin{array}{l}\text { Mental retardation }(n=35), \\
\text { "psychopathic disorder" }(n=39) \text {, } \\
\text { "mental illness" }(n=39)\end{array}$ & $\begin{array}{l}\text { Rape or attempted rape, sexual } \\
\text { abuse in children }\end{array}$ & $\begin{array}{l}\text { Degree of violence in sexual } \\
\text { crime directly proportional to I0 }\end{array}$ \\
\hline
\end{tabular}




\begin{tabular}{|c|c|c|c|c|c|c|}
\hline Authors & Year & Methodology & $\begin{array}{c}\text { Sample } \\
\text { (n) }\end{array}$ & Main Psychiatric Diagnosis & Sexual Offences & Factors and Associated Motives \\
\hline Hodgins27 & 1992 & Birth cohort study & 15.117 & $\begin{array}{l}\text { "Major mental disorders" (n } \\
=161) \text {, disorders related to } \\
\text { alcohol and drugs }(n=254) \text {, other } \\
\text { mental disorders }=188 \text { ), mental } \\
\text { retardation }(n=192)\end{array}$ & $\begin{array}{l}\text { Sexual aggression, rape and } \\
\text { other violent non-sexual offences }\end{array}$ & $\begin{array}{l}\text { Presence of "Major mental } \\
\text { disorders" and mental } \\
\text { retardation }\end{array}$ \\
\hline Day29 & 1994 & $\begin{array}{l}\text { Retrospective study } \\
\text { of Police and medical } \\
\text { documents }\end{array}$ & 47 & Mental retardation & $\begin{array}{l}\text { Rape or attempted rape or } \\
\text { sodomy, indecent exposure, } \\
\text { exhibitionism }\end{array}$ & $\begin{array}{l}\text { Precarious skills and lack of } \\
\text { intimate courting and sexual } \\
\text { relationships }\end{array}$ \\
\hline Lindsay et al.30 & 2004 & $\begin{array}{l}\text { Transversal evaluation of } \\
\text { individuals }\end{array}$ & 184 & $\begin{array}{l}\text { Mental retardation: sexual } \\
\text { aggressors }(n=106) \text {, other } \\
\text { offences }(n=78)\end{array}$ & $\begin{array}{l}\text { Abuse of minors, rape and } \\
\text { attempted rape, indecent } \\
\text { exposure, harassment/sexual } \\
\text { aggression }\end{array}$ & $\begin{array}{l}\text { Chaotic life style and } \\
\text { relationship problems }\end{array}$ \\
\hline Barron et al.31 & 2004 & Prospective study & 61 & Mental retardation & $\begin{array}{l}\text { Not specified. Sexual offences } \\
\text { represent } 21 \% \text { of the initial } \\
\text { crimes }\end{array}$ & $\begin{array}{l}\text { Associated psychopathology, } \\
\text { inefficiency of therapeutic } \\
\text { interventions }\end{array}$ \\
\hline Crocker et al.32 & 2006 & $\begin{array}{l}\text { Evaluation of } \\
\text { questionnaires filled in by } \\
\text { carers }\end{array}$ & 3.165 & Mental retardation & $\begin{array}{l}\text { Not specified. } \\
\text { Sexual offences represented } \\
9.8 \% \text { of the aggressive } \\
\text { behaviours }\end{array}$ & $\begin{array}{l}\text { Record of imprisonment and } \\
\text { previous aggressive behaviour, } \\
\text { living with relatives }\end{array}$ \\
\hline Rice et al.33 & 2008 & $\begin{array}{l}\text { Transversal evaluation of } \\
\text { individuals }\end{array}$ & 69 & Mental retardation & $\begin{array}{l}\text { Sexual abuse of children, sexual } \\
\text { coercion, indecent exposure }\end{array}$ & $\begin{array}{l}\text { Deviant sexual tendencies, } \\
\text { especially paedophilia }\end{array}$ \\
\hline Faria Achá et al.34 & 2011 & $\begin{array}{l}\text { Evaluation of medical } \\
\text { records }\end{array}$ & 89 & $\begin{array}{l}\text { Mental retardation }(n=21) \text {, } \\
\text { schizophrenia }(n=11) \text {, personality } \\
\text { disorder }(n=10) \text {, disorders } \\
\text { related to drugs } \\
(n=6) \text { : among sexual aggressors }\end{array}$ & Not specified & $\begin{array}{l}\text { Greater prevalence of mental } \\
\text { retardation and personality } \\
\text { disorder }\end{array}$ \\
\hline Lindsay et al.35 & 2001 & $\begin{array}{l}\text { Transversal evaluation of } \\
\text { individuals }\end{array}$ & 98 & Mental retardation & $\begin{array}{l}\text { Not specified: sexual aggressors } \\
(n=48) \text {, other offences }(n=50)\end{array}$ & $\begin{array}{l}\text { Having suffered sexual abuse in } \\
\text { childhood }\end{array}$ \\
\hline Blanchard et al.37 & 1999 & $\begin{array}{l}\text { Semi-structured } \\
\text { interviews, questionnaires, } \\
\text { phallometric tests }\end{array}$ & 678 & Mental retardation $(n=101)$ & $\begin{array}{l}\text { Abuse of minors: touching of } \\
\text { genitals, rape or attempted rape, } \\
\text { sadism, indecent exposure }\end{array}$ & $\begin{array}{l}\text { Presence of mental retardation } \\
\text { and advanced maternal age } \\
\text { related to offences against boys }\end{array}$ \\
\hline Lindsay et al. ${ }^{38}$ & 2002 & $\begin{array}{l}\text { Database study of the } \\
\text { evaluations of mental } \\
\text { health professionals }\end{array}$ & 62 & Mental retardation & $\begin{array}{l}\text { Rape or attempted rape, sexual } \\
\text { harassment, indecent exposure, } \\
\text { illicit sexual intercourse }\end{array}$ & $\begin{array}{l}\text { Difficulties with anger and } \\
\text { aggression, presence of mental } \\
\text { disorders, problems with the use } \\
\text { of alcohol }\end{array}$ \\
\hline McElroy et al. ${ }^{39}$ & 1999 & $\begin{array}{l}\text { Transversal evaluation of } \\
\text { individuals }\end{array}$ & 36 & $\begin{array}{l}\text { Disorders related to the use } \\
\text { of alcohol or drugs ( } n=30) \text {, } \\
\text { paraphilias ( } n=21) \text {, mood } \\
\text { disorders ( } n=22) \text {, impulse } \\
\text { control disorders }(n=14) \text {, } \\
\text { anxiety disorders }(n=13) \text {, eating } \\
\text { disorders }(n=6)\end{array}$ & $\begin{array}{l}\text { Rape or attempted rape, gross } \\
\text { sexual accosting on adults and } \\
\text { children, indecent exposure, } \\
\text { voyeurism }\end{array}$ & $\begin{array}{l}\text { Paraphilias in comorbidity with } \\
\text { mood disorders, anxiety and/ } \\
\text { or eating disorders. Record of } \\
\text { sexual abuse in childhood }\end{array}$ \\
\hline
\end{tabular}

In continuity we will describe the studies concerning the referred association.

\section{Sexual offences and schizophrenia and other psychotic disorders}

Although there is robust evidence from different countries indicating that psychotic disorders increase the risk of violent behaviour, the vision of specialists is that serious mental disorders have only a small role in sexual offences ${ }^{7}$. Mental disorder is not included among the risk factors for the commitment of rape according to the epidemiological studies, or sexual abuse, in review studies 9 . However, there is still no consensus in literature about the importance of this association. Studying this subject, Fazel et al. ${ }^{10}$ stated that risk factors for the perpetration of sexual offences include association aspects related to development (such as sexual abuse in childhood) and personal vulnerability (especially sexual deviant fantasies and triggering events, such as abuse of drugs).

A study of Craissati and Hodes ${ }^{11}$ investigated a subgroup of 11 men with schizophrenia, who had committed sexual offences or had shown antisocial sexual behaviour, being committed in a secure unit in England. According to these authors, the motivation related to the offence was predominantly related to sexual and aggressive impulses, with four patients admitting having perverse masturbatory fantasies, related to the period previous to the occurrence. It was verified that the mental state of six individuals who had interrupted the use of medication had deteriorated (showing irritability, social isolation, lack of care with personal appearance, explosive behaviour and disinhibited sexual attitude) some weeks prior to their offences. In the interviews undertaken during the study, two individuals confirmed that they were hallucinating at the time of the sexual offence. In this study, the aggressive sexual behaviour was associated predominantly with the relapse of the illness. It certainly must be taken into account that the sample was highly selected, consisting of individuals with serious mental disorders, who were committed in a secure unit.

Phillips et al. ${ }^{2}$, in a serial cases study, evaluated a group of $15 \mathrm{men}$ with a diagnosis of schizophrenia, hospitalized in a secure hospital unit in England, due to the perpetration of sexual offences. Seven of them had practised 14 rapes and eight had practised indecent exposure. It was found that the majority of the patients were symptomatic at the time of the sexual offence. Although 14 had reported contact with the mental health services, these contacts had been irregular, it being common that they often would miss their medical appointments. Only four patients had been receiving medication at the time of their offence. The sexual offence was considered as having occurred in the context of positive psychotic symptoms in 11 cases, whilst behaviour showing disinhibition was considered important in 13 cases. Ten patients presented persecutory delusions and 11 auditory hallucinations. Thirty-seven were victims of these patients, all of the female gender, in that a third of them were adolescents. In the majority of cases, the sexual violence happened after the beginning of the illness, over an average period of five years, while only three practised their offences before the onset of the illness. 
Smith ${ }^{13}$ investigated the relationship between schizophrenia and sexual offence, studying documents and records of 80 schizophrenic patients admitted to secure units in England, accused of sexual offences (rape, attempted rape and indecent assault) against women, committed in the acute phase of psychosis. The 80 patients showed symptoms such as delusions, hallucinations, formal thought disorders and incongruent affect. Regarding the relationship with the victims, 49 (61\%) were unknown and 31 (39\%) were known sexual aggressors. A total of $30(38 \%)$ of them reported consumption of alcohol or drugs before the sexual offence. Bizarre or notably strange behaviour was observed and described in $16(20 \%)$ of the men. This behaviour was related to phenomenology of psychosis, such as shouting back in response to auditory hallucinations, delusional speech, robotic and other strange movements.

In a case-control study, Fazel et al. ${ }^{10}$ all the sexual aggressors sentenced for a period of 13 years (1988 to 2000) in Sweden, were investigated. 8.495 men sentenced for sexual offences (rape, sex under coercion and sexual harassment of adults and children). The control group consisted of 19.935 men from the general population. A greater prevalence of psychiatric hospitalization and of serious mental disorders was found in the sexual aggressors, compared to the controls. The combined prevalence of serious mental disorders (schizophrenia and other psychosis, bipolar disorder and organic mental disorders) was $4.8 \%$ in sexual aggressors, compared to $1.3 \%$ in controls. The findings of this study suggest an important role of serious mental disorders in sexual offences. The risk factors established include previous sexual offence, young age, interpersonal relationship problems and deviant sexual preferences.

A study by Alden et al. ${ }^{14}$, examined the data of individuals born in Denmark, between the years of 1944 and 1947, through official records, who were accompanied till the year 1991. The final sample consisted of 173.559 men. It was verified that the men who had been hospitalized due to a psychotic disorder, compared to those who never had been hospitalized, had four times greater risk of having been imprisoned due to sexual offence. In the men with psychotic disorders without comorbidity with personality disorders or abuse of drugs, this risk was just two times higher. The other form, psychotic disorders not accompanied by personality disorders or disorders related to the use of drugs were less associated with the increase of imprisonment involving any sexual offence or aggressive sexual offence.

The role of schizophrenia in sexual offences also constitutes the subject of the research of Alish et al. ${ }^{15}$. These authors studied three groups of individuals: 36 sexual aggressors with schizophrenia, 80 men with schizophrenia with no record of sexual offence, but who had committed other offences (theft) and 57 sexual aggressors without schizophrenia (control group, originating from prisons in Israel). Of these 57, 29 received the diagnosis of paraphilia: paedophilia ( $\mathrm{n}$ $=22)$, exhibitionism $(n=4)$ and sadism $(n=2)$. Among the sexual aggressors with schizophrenia, 12 of them received the diagnosis of paraphilia: paedophilia $(n=8)$, exhibitionism $(n=4)$. All the patients with schizophrenia were from a forensic unity of a hospital in Israel. Curiously, it was found that among the individuals with schizophrenia who perpetrated sexual offences, there was a lower percentage of antisocial personality disorder (36\%), compared to the group with schizophrenia without a record of sexual offence (65\%). The sexual offences consisted of rape (50.5\%) and sexual violation with penetration (49.5\%). Furthermore it was found that among individuals with schizophrenia, there was a tendency for sexual aggression against women $(83.3 \%)$, while sexual aggressors without schizophrenia sexually attacked more men (58\%). Furthermore according to these authors, the high frequency of paraphilias (33\%) in the group of sexual offenders with schizophrenia may have created an important influence on this behaviour.

There is still no unequivocal conclusion concerning the clinical parameters that lead to a deviant sexual behaviour in the case of schizophrenia. The behaviour may not necessarily originate from the schizophrenic condition itself, but may be the result of a sexual deviation not related to the illness, or from suggestive characteristics of the presence of a personality disorder.

\section{Sexual crimes and mood disorder and others}

The offences perpetrated by individuals with bipolar disorder occur more frequently in the manic phase. In this phase the state of mood is high, with the presence of a contagious happiness or an irritability accompanied by hostility. Other symptoms such as the increase of self-esteem, feelings of grandiosity, grandiosity delusions, considering oneself to be a special person, endowed with powers and high intelligence, are frequently present. Apart from the latter, an increase in motor activity, thus showing great physical vigour and in spite of this, a reduction in the necessity for sleep. The patient shows a strong urge to speak uninterruptedly, with ideas flowing quickly to the point of not concluding what was initiated and always stringing one not concluded idea with another successively (flight of ideas) ${ }^{16}$.

A study ${ }^{17}$ of the population base, using hospital and criminal records, in Sweden, investigated individuals who received discharge from psychiatric hospitals and were monitored in relation to the perpetration of violent offences, for a period between 1973 and 2004. Individuals with diagnosis related to bipolar disorder $(\mathrm{n}=$ 3.743) were compared after two or more discharges from psychiatric hospitals with the general population $(n=37.429)$. Violent offences were considered to be: homicide, theft, arson, any offences of a sexual nature, or related to threat or intimidation. During the period of accompaniment, it was verified that the bipolar individuals committed significantly more violent offences of some kind (8.4\%) compared to those of the control group consisting of the general population (3.5\%). It was observed that this risk was especially greater in those patients who presented comorbidity with abuse of drugs.

Continuing to study the same subject matter, Curtin and Niveau ${ }^{18}$ undertook a retrospective study of expert documents of all the sexual aggressors who did not commit sexual homicide and for which a psychiatric evaluation was requested by the police authorities, in Geneva, Switzerland, in the period 1982 to 1995 . The objective of this study was to evaluate the penal responsibility of these individuals, according to the Swiss penal code. The sexual offences included rape, attempted rape and other similar acts against the will of the victim (sexual coercion). The 67 aggressors where separated in three groups: sexual aggressors whose victims were minors of 18 years old, who were not his or her relatives; sexual aggressors whose victims were minors of 18 years old and were their relatives (incestuous sexual offence) and sexual aggressors against adults, of 18 years old and over. It was found that around two thirds of the aggressors had no previous psychiatric history, and only between $9 \%$ and $15 \%$ had been admitted to psychiatric hospitalization. Alcohol dependence existed among $12 \%$ to $14 \%$ of the incestuous aggressors and aggressors against adults, respectively. Schizophrenia and other psychotic disorders were relatively rare (5\%), whilst affective disorders were diagnosed in $12 \%$ to $14 \%$ of the all the aggressors.

Furthermore in this study ${ }^{18}$, it was found that a history of sexual abuse in childhood was a predictor factor of sexual offence, indicating a fivefold greater risk of an individual committing a sexual offence against a child rather than against an adult. This is in accordance with other studies which show that a record of sexual abuse among molesters of children is twice greater than between rapists of adults. The presence of sexual trauma during infancy represents a serious factor of risk of sexual deviation during adulthood 9,19 .

Dunsieth et al. ${ }^{20}$ evaluated 113 men condemned for sexual offences, who were referred to treatment programmes, in Ohio, in the United States. Eighty-four men (74\%) were found to fulfil the diagnostic criteria for at least for one type of mental disorder. The psychiatric diagnosis most encountered were: disorders related to the use of drugs ( $\mathrm{n}=84,74 \%)$; paraphilias $(\mathrm{n}=84,74 \%)$; mood disorders $(\mathrm{n}=66,58 \%)$, with $\mathrm{n}=40(35 \%)$ for bipolar disorder; control of impulse disorder $(n=43,38 \%)$; anxiety disorders $(n=26,23 \%)$ and eating disorder $(n=10,9 \%)$.

In this same line of research, Leue et al. ${ }^{21}$ evaluated sexual aggressors from a forensic hospital in Germany. Individuals with psychosis $(n=12)$, illiteracy $(n=2)$ or intellectual impairment ( $=36)$ or neurological $(n=11)$ were excluded. The sample consisted 
of 55 individuals. The anxiety disorders were commonplace in this sample, the most frequent being simple phobia $(n=22,40 \%)$, social phobia $(n=21,38 \%)$ and post-traumatic stress disorder $(n=15,27 \%)$. Mood disorders were also highly prevalent in the sample, 29 (53\%) cases of major depression being found.

It is interesting to point out that in the opposite side, studies have found a greater prevalence of mental disorders, over the length of lifetime, in individuals victim of sexual violence. In a systematic revision, Chen et al. 22 found that a record of sexual abuse is a risk factor for the development of anxiety, depression, eating disorders, post-traumatic stress, sleep disorders including attempted suicide. This association was independent of the sex of the victim or age in which the abuse occurred. On the other hand, there was no association between sexual abuse and schizophrenia and somatoform disorders.

\section{Sexual crimes and mental retardation}

Mental disability includes a significant loss of intellectual capacity and of adaptive behaviour present right from childhood. The prevalence of mental retardation in the general population is $1.5 \%$ to $2.5 \%$. People with mental retardation are more vulnerable to the criminal justice system due to their lack of caution when they speak, their limited critical capacity in relation to the consequences of their behaviour and susceptibility to the influence of others ${ }^{23}$.

Studies of samples of patients under custody ${ }^{23,24}$, found a prevalence of almost $20 \%$ of individuals with IQ below 70 , with comorbidity related to drug abuse present in $60 \%$ of them. These offenders with low IQ had more previous convictions than those with no mental deficiency and had rarely been diagnosed for intellectual impairment. Other studies found less prevalence, around 7\% of individuals with IQ lower than 70 in prison units (Hayes et al., 2007 apud Sondenaa et al. ${ }^{25}$ - review study). There seems to be an ample variation in the identification of rates of prevalence of intellectual impairment in these prison populations, depending on the methods of evaluation, locations and cultures where these studies are undertaken.

Murrey et al. ${ }^{26}$ evaluated records of 106 male sexual aggressors of a secure unit of an hospital in Washington, U.S.A. Of these, 39 showed "psychopathic disorder", 39 showed mental illnesses and 35 presented mental retardation, characterized by the application of a WAIS intelligence scale. It was found that $88 \%$ of the victims of those with "psychopathic disorder", $98 \%$ of the victims of those with mental illness and $56 \%$ of the victims of those with mental retardation were women. The group with mental retardation had more men victims lower than 16 years old, compared to other groups. Regarding the practice of violence during the sexual crime itself, it was verified that $69 \%$ of those with "psychopathic disorder", $66 \%$ of the mentally ill and $51 \%$ of those with mental retardation were violent in at least one sexual offence. Thus, when there was an increase in IQ, this characteristic increased the probability of violence during the sexual offence. Another finding was that a quarter of those with "psychopathic disorder" and mental illness committed at least one crime with penile penetration of the vagina, whilst the proportion of individuals with mental retardation who committed this type of offence was minimal. The problem with this study is that the authors did not define the meaning of "psychopathic disorder" and neither the mental disorders of the individuals of this sample.

In a study with all the criminals in Denmark, Hodgins ${ }^{27}$, described that all those with intellectual impairment and "major mental disorders" had a greater risk of violent behaviour. Unfortunately the violent aggressors were not differentiated, including assault, rape, theft and sexual aggression. These individuals presented intellectual impairment $(n=192)$, "major mental disorders" $(n=161)$, including those with schizophrenia, major affective disorders, paranoid states and other forms of psychosis; mental disorders and behaviours related to the use of alcohol and/or drugs $(n=254)$; other mental disorders $(\mathrm{n}=188)$. Sundram (1989 apud Lindsay 28 - review study) also described a high frequency of serious crimes, including sexual aggressions, with $38 \%$ of hospital inmates with IQ below 70 in prisons of New York having committed or attempted to commit homicide and sexual offences.

Day ${ }^{29}$, studying the same subject, carried out a retrospective study on the behaviour of individuals with intellectual impairment admitted to a hospital for treatment for anti-social sexual behaviour, in England, whether this had or not resulted in imprisonment, during the period of 1970 to 1988 . Forty-seven patients were found to have committed a total of 191 sexual incidents, involving 202 victims. More than half $(55.5 \%)$ were heterosexual incidents. Others were crimes of indecent exposure (24.6\%), homosexual offences (12\%), in that only $3.6 \%$ involved physical aggression. In this study it was found that the majority of incidents were relatively trivial, $60 \%$ involving minor incidents of indecent exposure. The other finding of this sample was a high prevalence of mental disorders, minor physical incapacities, precarious social skills and sexual recidivism. Furthermore according to this author ${ }^{29}$, it is infrequent that individuals with intellectual impairment commit aggressions involving serious bodily harm, violence or death.

Another finding of the study of Day ${ }^{29}$, was the low specificity of the age and sex of the victims, suggesting circumstances and opportunity, more than preference or sexual orientation, being the most important in the choice of victim and type of sexual offence committed by the vast majority of cases. It was also found that none of the heterosexual offenses occurred in the context of an established relationship or in a developing one. This can reflect precarious skills with relationships and the lack of opportunity for courting and sexual relationships in individuals with intellectual disabilities.

Another study ${ }^{30}$ compared two samples of offenders with intellectual impairment. Those who perpetrated sexual offences and were involved in incidents of sexual abuse were compared to other offenders whose offence had no sexual content. The sample consisted of 106 sexual aggressors and 78 non-sexual offenders. All were admitted to community treatment service in Scotland. It was found that a significantly higher proportion of sexual aggressors had a chaotic life style $(32 \% \times 16 \%)$ and had problems of relationship (52\% and $24 \%$ ), compared to non-sexual offenders. Regarding the types of sexual offences, $33 \%$ committed lascivious and libidinous (offences without penetration in minors); $26 \%$ sexual aggression; $21 \%$ indecent exposure; $11 \%$ illegal sexual intercourse (2\% for each). Some individuals committed more than one type of sexual offence. Regarding the aspect of criminal recidivism, this occurred more significantly with the group of non-sexual offenders (51\%) than with the group of sexual aggressors (19\%).

This subject was also studied by Barron et al. ${ }^{31}$. In a prospective study, these authors undertook the accompaniment for two years of individuals with intellectual impairment (IQ below 80), in London, in England. All the offenders had perpetrated some offence in the previous five years before the study. The group consisted of 61 individuals. The most common types of initial offences were violence (37.7\%), sexual offences (21\%) and those related to property (15\%). Violence (57.4\%) was also the most common offence, when all the records of the criminal history were analysed, followed by crimes against property (52.5\%), sexual (47.5\%) and arson (21.3\%). A high frequency of psychopathology was found (52\%), especially psychotic disorders (43\%). Half the total sample showed criminal recidivism, however the study did not describe what these further crimes were. We highlight that in this study the authors did not specify what was considered as violence.

The aggressive behaviour may represent an important obstacle for integration with society of individuals with mental retardation. A study of Crocker et al. ${ }^{32}$, evaluated prevalence and seriousness of five types of aggressive behaviour in 3.165 adult men and women with mental retardation, who received assistance in three rehabilitation centres in Quebec-Canada. The annual prevalence of aggressive behaviour found was $51.8 \%: 24 \%$ committed damage to property, $37.6 \%$ verbal aggression, $24.4 \%$ self-mutilation, $24.4 \%$ physical aggression and $9.8 \%$ showed aggressive sexual behaviour. Only $4.9 \%$ of these individuals showed aggressive behaviour that produced physical harm to the victim. 
In another study ${ }^{33}$, sexual interest established through phallometric study, recidivism and choice of victims of 69 sexual aggressors with mental retardation were examined and compared with the data of 69 aggressors with much higher IQ (control). It was found that the aggressors with mental retardation showed more deviant sexual preferences for boys and young children than the control group. Compared to the control group, these sexual aggressors did not show greater risk of preferences for coercive sexual activities against children, and neither had a greater risk of violent recidivism. In turn, a Brazilian study ${ }^{34}$ with individuals who were committed in a forensic hospital compared sexual offenders and non-sexual offenders, finding a significantly higher level of mental retardation and personality disorder in individuals who perpetrated sexual offences.

Continuing to study this subject Lindsay et al. ${ }^{35}$ compared 48 sexual aggressors and 50 non-sexual offenders with intellectual impairment, finding a significantly higher frequency record of sexual abuse in the group that committed sexual offence (38\% x 12.7\%) and a significantly higher frequency of physical abuse in the group which perpetrated other offenses ( $14 \times 36 \%)$. According to these authors, this finding reinforces the hypothesis that the type of abuse suffered in childhood may be related to the type of crime committed in adult life.

In relation to the victims targeted, there does not seem to be a consensus between different authors. Day ${ }^{29}$ reported that individuals with intellectual disabilities frequently committed more heterosexual offenses against adult victims; while Hayes ${ }^{36}$, in a review study stated that these individuals targeted men more than women. In a study with 950 sexual offenders, Blanchard et al. ${ }^{37}$ found that sexual aggressors with intellectual impairment showed greater probability of committing offences against young children and boys. However, according to Lindsay et al. ${ }^{38}$, these aggressors probably committed sexual offences in all categories and discriminated their victims less.

For Barron et al. ${ }^{31}$, the therapeutic interventions for individuals with intellectual disabilities seem to be relatively unspecific and not focussed. Perhaps there are difficulties of a practical nature for the supply of these interventions in this group of individuals, including lack of trained teams in specific psychosocial interventions and with ability of diagnosing and adequately treating mental disorders and disorders related to the comorbid use of alcohol and drugs, when present in these individuals. This indicates the necessity of more study concerning this population and team training, in such a way as to offer adequate treatments for these individuals. Approaches related to the sexuality of these individuals with intellectual impairment could reduce this type of offence in them. Treatment methods should focus on sexual education, counselling, training in social abilities, better self-image, self-esteem and social conscience.

Considering its relevance, sexual aggressors with intellectual impairment have been neglected by scientific literature. Certainly the studies on this subject would imply in the prevention of offences, adequate evaluation and treatment of these offenders, as well as the development of services of specific assistance for this population.

In table 1 we describe a summary of the studies which evaluated the samples of the individuals who perpetrated sexual offences.

\section{Discussion}

In this review, some research studies with samples of individuals associated schizophrenia, bipolar disorder and mental retardation with perpetration of sexual offences. However, it is necessary to take into consideration that some of these studies evaluated selected samples of patients in psychiatric hospitals or secure hospital uni ts $^{11-13,15,18,20,24,26,29,33,34}$ and who were admitted to these locations due to the perpetration of sexual offences. For this reason, it would be expected that these disorders should be present in these studies. Another aspect is that several research studies with large samples of individuals have shown a high frequency of disorders related of alcohol and drugs ${ }^{27}$ and personality disorders ${ }^{10}$, among perpetrators of sexual offences. Although the latter disorders just mentioned were not the object of specific investigation in this review, it is possible that their contribution to the perpetration of sexual offences is important. Certainly, the objective of research studies about the relationship between sexual offences, mental disorder and mental retardation is not to stigmatize, but rather to better understand the factors which contribute to the perpetration of these offences by these individuals, as well as to propose therapeutic interventions for them.

For McElroy et al. ${ }^{39}$, the knowledge of the types and prevalence of mental disorders in sexual aggressors is important for several reasons. Firstly, a better understanding of the relationship between mental disorder and sexual violence can enable the development of more effective legal, correctional and public health policies, directed to individuals who have committed sexual offences. Secondly, the appropriate psychopharmacological treatment of mental disorders of these individuals, administrated together with psychosocial and correctional treatments, may increase the chances of successful rehabilitation, in this way reducing the criminal recidivism, public victimization and use of high cost correctional services. Thirdly, factors of risk and strategies of prevention against sexual violence can be identified and developed.

Caparulo ${ }^{40}$, in a review study, pointed out variations which are important in the evaluation of risk in the case of sexual aggressors. These include cooperation with evaluation, record of previous sexual offence, record of criminality and violence, temper and anger control, desire to discuss the offence, acceptance of responsibility, expression of remorse, deviant sexual interest, perversions, types of victims, abuse of drugs, empathy with the victim, mental disorder, record of abuse suffered and motivation towards treatment.

The observational study of sexual aggressors with schizophrenia contribute to the understanding of this offence by these individuals and the evaluation of comorbid conditions to schizophrenia, apart from the elucidation of the penal responsibility and definition therapy strategies. In this aspect, $S_{m i t h}{ }^{13}$ suggests that the factors that lead to sexually offensive behaviour in schizophrenia are antisocial personality characteristics and the use of alcohol and drugs by these individuals. However, as already mentioned, there is no unequivocal conclusion regarding which clinical parameters lead to a deviant sexual behaviour: if the illness itself, the characteristics of personality, or sexual preoccupations which lead the patient to commit the sexual offence. Undoubtedly, the serious mental disorders are associated with hostility, cognitive distortions, deviant sexual fantasies, sexual obsessions and precarious social skill, which are considered risk factors for sexual offences. Also one cannot fail to consider that mental disorders may act as social desinhibitory, interacting with other risk factors, such as alcohol and drug abuse.

Some authors have tried to explain the association between intellectual deficiency and sexual offences. For Duque ${ }^{41}$, sexual offences are overrepresented among those with intellectual disabilities, due to the reduction of self-control, the difficulty of adapting to rules or to inadequate comprehension of the facts. Faulk ${ }^{7}$ considers that individuals with mental retardation frequently make inadequate sexual approaches, which can lead to sexual aggression. Others can give vent to sexual aggressions at several levels, as an expression of anger or sexual frustration. Day ${ }^{29}$ observed in these individuals sexual naivety, incapacity to understand normal sexual relations, lack of social relation skills, difficulty in bonding with the opposite sex, precarious impulse controls and susceptibility to be influenced by other people. Hayes ${ }^{36}$ indicated that these individuals showed a confused self-concept, poor social relations, lack of social and sexual knowledge, and negative early experiences (including physical and sexual abuse).

There is evidence of a precarious identification of offenders with intellectual impairment by the criminal justice system and inconsistent responses and inadequate health and social services to respond to the challenge presented by these individuals.

Lindsay et al. ${ }^{38}$, studying a sample of sexual aggressors with intellectual impairment, between the years of 1990 to 1997, stated that $32 \%$ of these individuals showed significant mental disorder, including psychotic disorders, bipolar disorder and major depression. It is fundamental that individuals with intellectual impairment 
receive psychiatric and psychosocial interventions, in such a way as to prevent new sexual and non-sexual offences.

On the other hand, Lindsay et al. ${ }^{42}$, state that people with intellectual impairment may be disadvantaged by the criminal justice system, due to their lack of understanding of the seriousness of the situation, lack of support and lack of appropriate representation in the early stages of a lawsuit. Gudjonsson and MacKeith ${ }^{43}$ conducted a series of studies showing that individuals with intellectual impairment are more vulnerable to perjury during an interrogatory interview, due to their higher propensity to acknowledging agreement and due to their suggestibility.

In the research related to sexual offences, an important question is the evaluation of risk. According to Monahan and Steadman (1994), apud Gonçalves and Vieira ${ }^{1}$, the evaluation of risk of violence supposes an organized and systematic procedure, to characterize the degree of risk by certain individuals to commit a violent act, as well as the development of a plan of intervention to reduce this risk of violence. The evaluation of risk includes information regarding the following aspects: place of the offence, probability of the offence occurring again, frequency and consequences of the offence.

For Craig et al. ${ }^{44}$, any evaluation concerning the probability of the occurrence of sexual offences should be ample and involve more than one set of documentation regarding the degree of risk. According to these authors, the types of risk factors identified in the literature are classified in four categories: Dispositional factors, such as psychopathic or anti-social personality characteristics; Factors of life history, such as adverse events during development (for example, precarious links with their parents, behavioural problems at school), previous record of crime and violence, previous psychiatric hospitalization and precarious adherence and collaboration with treatment; records of violence, deviant social network and absence of positive social support; Clinical factors, such as psychiatric diagnosis, precarious level of functioning and abuse of substances.

In another study, Hanson and Harris (2000), apud Craig et al.44 informed that in the month prior to sexual offence, there was a marked alteration in a number of acute dynamic factors. The appearance and the collaboration with supervisors deteriorated; furthermore there were frequent negative mood, anger and psychotic symptoms. From this point onwards, these factors seem to signal a progressive escalation, in the risk factor of these aggressors. The mental disorders such as psychotic and mood disorders are included as dynamic risk factors. The consideration of dynamic factors next to the present static classification of risk may give a more global and valid evaluation of risk of recidivism of sexual offence by these aggressors. We highlight some instruments of sexual violence risk assessment in the following paragraphs.

The risk of recidivism of sexual offences may be evaluated through the use of STATIC $99^{45}$. This instrument makes use of static factors (immutable) which have been considered in literature as having a correlation with recidivism of sexual offences in adult men. The instrument consists of 10 items: 1) having a current record of sexual offence; 2) having a record of previous sexual offences; 3 ) having a current conviction of non-sexual violence; 4 ) having previous conviction for non-sexual offence; 5 ) having four or more convictions registered in criminal records; 6) being single; 7) having a record of sexual offences with no physical contact; 8) having unknown victims; 9) having male victims; 10) being between 18 and 25 years of age. This instrument gives an explicit estimate of probability of a new conviction for sexual offences, and can be easily applied and has shown itself to have a high capacity of predictability in different settings and in a variety of samples.

Another instrument, the Sexual Violence Risk-20 (SVR-20)1, is considered to be of extreme importance in the evaluation of risk of sexual violence. It consists of a number of items which are referenced in literature as being predictors of sexual violence. It is divided in three main areas: Psychosocial adjustment (sexual deviation, victim of abuse in infancy, psychopathy, serious mental disturbance, problems associated with the use of drugs, record of violent and non-violent offences etc.); Sexual Offences (high frequency of sexual offences, sexual offences of multiple types, sexual offences with physical aggressions or use of weapons, attitudes of support or belittling of the sexual offences) and Future Plans (absence of realistic plans, negative attitudes in the face of intervention).

The instrument Sex Offence Risk Appraisal Guide (SORAG) ${ }^{45}$ has 14 items which include: having lived with both biological parents up to the age of 16 years old, bad adjustment at school, problems with alcohol, evidence of a lasting intimate relationship, non-violent criminal record, violent criminal record, prior imprisonment for sexual offences, offences only against girls less than 14 years old, loss of previous parole, age at the first offence, evidence of personality disorder, schizophrenia, evidence of deviant sexual preferences and psychopathy.

Studying this subject, Lindsay et al. (2004), apud Lindsay and Taylor ${ }^{46}$ conducted a study to evaluate the criminal recidivism of 52 individuals with mental retardation who committed sexual offences, accompanied for a period of three years after discharge from hospital. It was found that factors which were related with criminal recidivism were antisocial attitude, precarious relationship with their mother, low self-esteem, lack of assertiveness, low response to treatment, offences involving physical violence, complacency of the treatment team and tolerant attitude towards sexual offences, low motivation towards treatment, irregular attendance, deterioration of attitudes of the family and non-programmed discharge.

In this review study, the authors did not find a description of the specific instruments of risk evaluation of recidivism of sexual offences among those with mental retardation. However, the scales mentioned previously, with its several items, did not exclude these individuals. Some scales of evaluation of sexual knowledge, sexual attitudes and sexual education have been applied to individuals with mental retardation, contributing to the evaluation of risk in these cases. According to Lindsay and Taylor ${ }^{46}$, the most used has been the Socio-Sexual Knowledge and Attitudes Test. It has been found that individuals with mental retardation show less sexual knowledge than the normal controls.

In this review study we found several factors associated to, as well as motivators of sexual offences, also mentioned as important for recidivism of these offences, according with these instruments cited above: presence of serious mental disorders such as schizophrenia ${ }^{10-15,18,34}$, bipolar disorder ${ }^{10,14,17,18,20,39}$, existence of sexual deviants $10,13,15,20,21,33,39$, presence of personality disorders ${ }^{14,18,24,34}$, problems associated with the use of alcohol and/or substances $6,14,15,17,18,20,27$, seriousness of sexual aggression ${ }^{10-15,18,20,21,26-28,37-39}$, record of abuse in childhood $18,35,39$, problems of relationships ${ }^{29,30,38}$, aggressive behaviour, previous record of imprisonment ${ }^{32}$, and absence of response to treatment ${ }^{31}$. We believe that the observation of all these factors in the clinical record of these individual is fundamental, as well as the diagnostic and adequate treatment of mental and developmental disorders presented by them. Furthermore, cognitive-behavioural psychotherapy is important for the cognitive distortions and deviant fantasies associated to sexual offences, as well as approaches and guidance of the respective relatives, in such a way to reduce the recidivism of sexual offences.

According to Serafim et al. ${ }^{47}$, in a review study, the evaluation of sexual aggressors according to behaviour, type of victim, motivation and risk recidivism is only possible in an interdisciplinary context, with the participation of a psychiatrist, psychologist and a social assistant. There is a need for this team to establish those who respond to the available therapeutic interventions, reducing the risk of recidivism.

The research about etiology of sexual offences and evaluation of sexual aggressors is the only way to reduce the consequences and cost of these problems for society, as well as the immense suffering brought to the victims. Studies concerning sexual offenses may contribute to the evaluation of risk of violent sexual behaviour. In turn, this evaluation would be useful for the planning of therapeutic interventions and clinical handling of these individuals, in the community, in prisons or by forensic psychiatric service providers. 


\section{Conclusion}

More studies are necessary regarding the association between mental disorders and mental retardation and sexual offences, using larger samples and investigating factors of risk for sexual aggression, in these individuals. The detection and treatment of psychiatric morbidity among sexual aggressors in health and criminal justice systems, may contribute to a lower risk of recidivism. The systematic psychiatric evaluation of individuals who perpetrate sexual offences may contribute to the strategy of intervention, prevention and evaluations of the specific motivations related to the manifestation of violent sexual behaviour, as well as permit a better characterization of groups or situations of risk.

\section{References}

1. Gonçalves RA, Vieira S. A avaliação do risco de violência sexual. Psicologia: Teoria, Investigação e Prática. 2004;2:65-80.

2. DEPEN. Ministério da Justiça. Homepage: <http://portal.mj.gov.br/ depen/data/Pages/MJC4D50EDBPTBRIE.htm>.

3. Rosa e Campos MAM, Schor N. Violência sexual como questão de ordem pública: importância da busca ao agressor. Saúde Soc. 2008;17(3):190200.

4. Finkelhor D, Hotaling G, Lewis IA, Smith C. Sexual abuse in a national survey of adult men and women: prevalence, characteristics, and risk factors. Child Abuse Negl. 1990;14(1):19-28.

5. Baltieri DA, Andrade AG. Alcohol and drug consumption among sexual offenders. Forensic Sci Int. 2008;175:31-5.

6. Prentky RA, Knight RA. Identifying critical dimensions for discriminating among rapists. J Consult Clin Psychol. 1991;59(5):643-61.

7. Faulk M. Basic Forensic Psychiatry. 2nd ed. London: Blackwell Scientific Publications; 1994. p. 271-86.

8. Spitzberg BH. An analysis of empirical estimates of sexual aggression victimization and perpetration. Violence Vict. 1999;14:241-60.

9. Hilton M, Mezey G. Victims and perpetrators of child sex abuse. Br J Psychiatry. 1996;169:408-15.

10. Fazel S, Sjostedt G, Langstrom N, Grann M. Severe mental illness and risk of sexual offending in men: a case control study based on Swedish national registers. J Clin Psychiatry. 2007;68:588-96.

11. Craissati J, Hodes P. Mentally ill sex offenders. The experience of a regional secure unit. Br J Psychiatry. 1992;161:846-9.

12. Phillips SL, Heads TC, Taylor PJ, Hill GM. Sexual offending and antisocial behavior among patients with schizophrenia. J Clin Psychiatry. 1999;60(3):170-4.

13. Smith AD. Offence characteristics of psychotic men who sexually assault women. Med Sci Law. 2000;40(3):223-8.

14. Alden A, Brennan P, Hodgins S, Mednick S. Psychotic disorders and sex offending in a Danish birth cohort. Arch Gen Psychiatry. 2007;64(11):1251-8.

15. Alish Y, Birger M, Manor N, Kertzman S, Zerzion M, Kotler M, et al. Schizophrenia sex offenders: A clinical and epidemiological comparison study. Int J Law Psychiatry. 2007;30:459-66.

16. Moreno RA, Moreno DH, Ratzke R. Diagnóstico, tratamento e prevenção da mania e da hipomania no transtorno bipolar. Rev Psiq Clín. 2005;32(Supl 1):39-48.

17. Fazel S, Lichtenstein P, Grann M, Goodwin GM, Långström N. Bipolar disorder and violent crime: new evidence from population-based longitudinal studies and systematic review. Arch Gen Psychiatry. 2010;67(9):931-8.

18. Curtin F, Niveau G. Psychosocial profile of Swiss sexual offenders. J Forensic Sci. 1998;43(4):755-9.

19. Seghorn TH, Prentky RA, Boucher RJ. Childhood sexual abuse in the lives of sexually aggressive offenders. J Am Acad Child Adolesc Psychiatry. 1987;26:262-7.

20. Dunsieth NW, Nelson EB, Brusman-Lovins LA, Holcomb JL, Beckman DA, Welge JA, et al. Psychiatric and legal features of 113 men convicted of sexual offenses. J Clin Psychiatry. 2004;65(3):293-300.

21. Leue A, Borchard B, Hoyer J. Mental disorders in a forensic sample of sexual offenders. Eur Psychiatry. 2004;19:123-30.

22. Chen LP, Murad H, Paras ML, Colbenson KM, Sattler AL, Goranson $\mathrm{EN}$, et al. Sexual abuse and lifetime diagnosis of psychiatric disorders: systematic review and meta-analysis. Mayo Clin Proc. 2010;85(7):618-29.
23. Dwyer RG, Frierson RL. The presence of low IQ and mental retardation among murder defendants referred for pretrial evaluation. J Forensic Sci. 2006;251:678-82.

24. Crocker AG, Mercier C, Allaire JF, Roy ME. Profiles and correlates of aggressive behavior among adults with intellectual disabilities. J Intellect Disabil Res. 2007;51:786-801.

25. Sondenaa E, Rasmussen K, Nottestad JA. Forensic issues in intelectual disability. Curr Opin Psychiatry. 2008;21:449-53.

26. Murrey GJ, Briggs D, Davis C. Psychopathic disordered, mentally ill, and mentally handicapped sex offenders: a comparative study. Med Sci Law. 1992;32(4):331-6.

27. Hodgins S. Mental disorder, intellectual deficiency and crime: evidence from a birth cohort. Arch Gen Psychiatry. 1992;49:476-83.

28. Lindsay WR. Research and literature on sex offenders with intellectual and developmental disabilities. J Intellect Disabil Res. 2002;46(Suppl 1):74-85.

29. Day K. Male mentally handicapped sex offenders. Br J Psychiatry. 1994;165:630-9.

30. Lindsay WR, Smith AHW, Law J, Quinn K, Anderson A, Smith A, et al. Sexual and nonsexual offenders with intellectual and learning disabilities. J Interpers Violence. 2004;19(8):875-90.

31. Barron P, Hassiotis A, Banes J. Offenders with intellectual disability: a prospective comparative study. J Intellect Disabil Res. 2004;48:69-76.

32. Crocker AG, Mercier C, Lachapelle Y, Brunet A, Morin D, Roy ME. Prevalence and types of aggressive behaviour among adults with intellectual disabilities. J Intellect Disabil Res. 2006;50:652-61.

33. Rice ME, Harris GT, Lang C, Chaplin TC. Sexual preferences and recidivism of sex offenders with mental retardation. Sex Abuse. 2008;20(4):409-25.

34. Faria Achá MF, Rigonatti SP, Saffi F, Martins de Barros D, Pádua Serafim A. Prevalence of mental disorders among sexual offenders and non-sexual offenders. J Bras Psiquiatr. 2011;60(1):11-5.

35. Lindsay WR, Law J, Quinn K, Smart N, Smith AHW. A comparison of physical and sexual abuse histories: sexual and non-sexual offenders with intellectual disability. Child Abuse Negl. 2001;25:989-95.

36. Hayes S. Sex offenders. J Intellect Dev Disabil. 1991;17:220-7.

37. Blanchard R, Watson M, Choy A, Dickey R, Klassen P, Kuban N, et al. Paedophiles: mental retardation, maternal age and sexual orientation. Arch Sex Behav. 1999;28:111-27.

38. Lindsay WR, Smith AHW, Law J, Quinn K, Anderson A, Smith A, et al. A treatment service for sex offenders and abusers with intellectual disability: characteristics of referrals and evaluation. J Appl Res Intellect Disabil. 2002;15:116-74.

39. McElroy SL, Soutullo CA, Taylor P, Nelson EB, Beckman DA, Brusman LA, et al. Psychiatric features of 36 men convicted of sexual offenses. J Clin Psychiatry. 1999;60:414-20.

40. Caparulo F. Identifying the developmentally disabled sex offender. Sex Disabil. 1991;9:311-22.

41. Duque C. Parafilias e crimes sexuais. In: Taborda JGV, Chalub M, Abdala-Filho, E, editors. Psiquiatria Forense. Porto Alegre: Artmed 2004. p. 298-314.

42. Lindsay WR, Michie AM, Staines C, Culross G, Bellshaw L. Increases in knowledge following a sex education course for people with intellectual disability. J Intellect Disabil Res. 1992;36:531-9.

43. Gudjonsson GH, MacKeith J. Learning disability and the police and criminal evidence act 1984. Protection during investigative interviewing: a video recorded false confession to double murder. J Forensic Psychiatr. 1994;5:35-49.

44. Craig LA, Browne KD, Beech AR, editors. Assessing risk in sex offenders. London: John Wiley \& Sons; 2008. p. 23-110.

45. Craig LA, Beech AR, Harkins L. The predictive accuracy of risk factors and frameworks. In: Beech AR, Craig LA, Browne K. Assessment and treatment of sex offenders.UK: John Wiley \& Sons Ltd; 2009. p. 53-74.

46. Lindsay WR, Taylor JL. The assessment of treatment - related issues and risk in sex offenders and abusers with intellectual disability. In: Beech AR, Craig LA, Browne K. Assessment and treatment of sex offenders. UK: John Wiley \& Sons Ltd; 2009. p. 217-35.

47. Serafim AP, Saffi F, Rigonatti SP, Casoy I, Martins de Barros D. Perfil psicológico e comportamental de agressores sexuais de crianças. Rev Psiq Clín. 2009;36(3):105-11. 